\title{
Postbiotics, as Dynamic Biomolecules, and Their Promising Role in Promoting Food Safety
}

\author{
Aziz Homayouni Rad ${ }^{1}{ }^{(\mathbb{D}}$, Leili Aghebati-Maleki ${ }^{2}{ }^{\mathbb{D}}$, Hossein Samadi Kafil ${ }^{3}{ }^{\mathbb{D}}$, Neda Gilani ${ }^{4}{ }^{\mathbb{D}}$, Amin \\ Abbasi 1, 2 (D), Nader Khani 1,3, * (D) \\ 1 Department of Food Science and Technology, Faculty of Nutrition \& Food Sciences, Nutrition Research Center, Tabriz \\ University of Medical Sciences, Tabriz, Iran; homayounia@tbzmed.ac.ir (A.H.R.), aminabasi.tbz.med.ac@gmail.com \\ (A.A.); \\ 2 Immunology Research Center, Tabriz University of Medical Sciences, Tabriz, Iran; Aghebatil@ tbzmed.ac.ir (L.A.M.); \\ 3 Drug Applied Research Center, Tabriz University of Medical Sciences, Tabriz, Iran; amirh_samadi@yahoo.com (H.S.K.); \\ 4 Department of Statistics and Epidemiology, Faculty of Health, Tabriz University of Medical Sciences, Tabriz, Iran; \\ neda.gilani@gmail.com (N.G.); \\ * Correspondence: naderxani1996m@gmail.com;
}

Scopus Author ID 57215873145

Received: 10.02.2021; Revised: 7.03.2021; Accepted: 11.03.2021; Published: 23.03.2021

\begin{abstract}
Many factors threaten food safety, such as physical, chemical, and biological hazards. In this regard, biological hazards are of paramount importance. Among them, the bacteria play important roles in causing food spoilage and food-borne diseases. Besides, a new approach has been used in recent years, which is based on probiotics and postbiotics to control the growth of pathogenic germs and their mediated corruption due to their significant antimicrobial properties. The outcomes of recent investigations suggest that postbiotics might be appropriate alternative elements for probiotic cells and can be employed as novel antimicrobial agents. The main antimicrobial mechanisms of postbiotics include acidifying the cellular cytoplasm and preventing energy regulation and production, suppressing the growth of pathogenic microorganisms by the formation of pores in cell membranes, and morphological and functional changes of sensitive components such as proteins and peptides by creating acidity in the bacterial cell membrane as well as inducing the oxidation of bacterial cells. Therefore, presently scientific literature approves that postbiotics can be applied as promising tools in food practice to prevent microbial corruption and develop functional foods due to their unique features. This review addresses the latest postbiotic applications with regards to food safety. Potential postbiotic applications in the inhibition of food spoilage and pathogenic microbes, food biopreservation, and biofilm control are also reviewed.
\end{abstract}

Keywords: probiotic; postbiotic; antimicrobial activity; food safety; functional food; gut microbiota.

(C) 2021 by the authors. This article is an open-access article distributed under the terms and conditions of the Creative Commons Attribution (CC BY) license (https://creativecommons.org/licenses/by/4.0/).

\section{Introduction}

Safe food can become hazardous to many food-transmitted diseases. A healthy diet pattern is the first step in ensuring the physical health of human beings. Safe and healthy food is free of food-borne, pathogenic germs [1]. On the other hand, if the food is contaminated with both microbially and/or chemically hazards, it may cause some serious diseases [2]. Contaminated foods can lead to the development of infectious diseases, affecting the whole world [3]. To deal with food problems, an important issue is food safety [4, 5]. Food safety means ensuring that the food does not harm the consumer when preparing and consuming [6]. Recently, the concept of food safety has become increasingly self-centered because unsafe 
foods cause problems and pathogenicity, especially in sensitive people (infants, young children, elderly, and patients) [7, 8]. Food safety is an important issue for consumers and producers. In European industrial and academic societies, many efforts have been made to increase food safety. Safe foods should be free of any contamination. It is essential to set up a complex of control systems to reduce the risk of the presence of contaminants in foods and thus increase food safety [9]. To enhance food safety in industrialized and developed countries, various standards, such as GAP (good agricultural production practices), GHP (good hygiene practices), GMP (good production management systems), and HACCP (hazard analysis and critical control point), have been developed [10]. Despite these efforts, there are 23 million food-borne diseases and 5,000 deaths in Europe annually because of poor food safety. Risk factors for food safety include physical factors (hair, animal waste, colored patches, grease, and paper), chemicals (heavy metals, pesticide residues, agricultural pesticide residues, antibiotics, and biogenic amines), and biological factors (parasites, viruses, bacteria, and fungi) [11]. Bacteria play a major role in threatening food safety, as they are capable of causing spoilage and pathogenicity. Some examples of food safety-threatening bacteria include Salmonella spp, Campylobacter jejuni, Staphylococcus aureus, Clostridium spp, Escherichia coli, and Listeria spp [12].

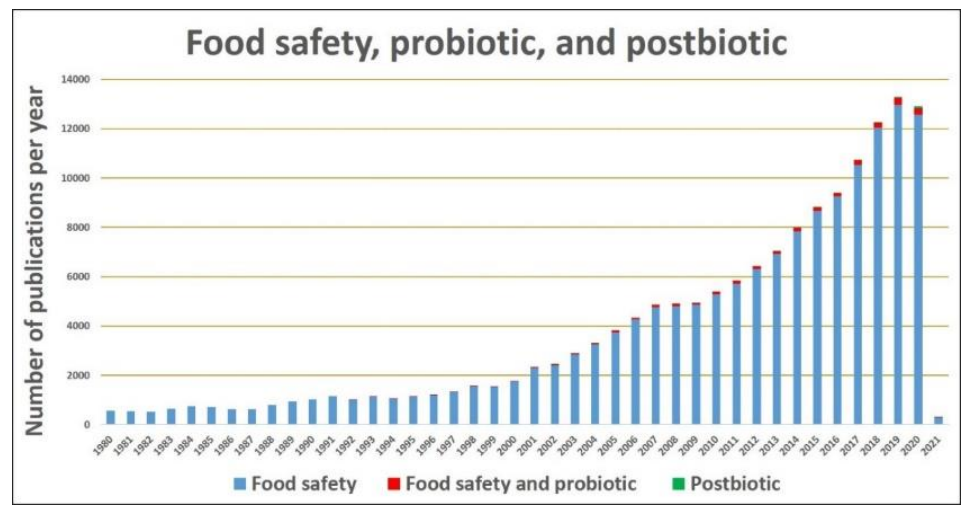

Figure 1. Illustrates the increase in the number of papers in the food safety field. Comparison between the number of publications with a focus on food safety, food safety and probiotic, and postbiotic in PubMed December 2020.

As mentioned above, one of the main factors that affect food safety and quality is the contamination of foods via pathogenic microbes throughout various manufacturing processes. Therefore, pathogenic microbial growth inhibition is the main approach to maintain food safety and control food-borne diseases. In recent decades, various methods have been employed for this purpose; for instance, the application of bioactive agents, such as probiotics and their byproducts to inhibit pathogenic microbial growth and subsequently promote the shelf life of food are considered as novel strategies, particularly in developing countries [13]. Despite favorable effects of probiotics, the results of some studies have indicated particular adverse clinical and technological effects of probiotics (e.g., the existence of virulence factors in some probiotic microbial strains, diverse patterns of colonization capable of preventing the standard colonization of other microbiota, mainly in neonates, metabolic disturbances including biogenic amine production, the lack of clear clinical recommendations, and the lack of large and long-term clinical trials). Therefore, postbiotics may be suitable substitutes for living probiotic cells due to their specific characteristics [14] (Figure 1). This study highlights the definitions and characteristics of postbiotics and their latest applications in improving food 
safety. Potential postbiotic applications in controlling spoilage and pathogenic microbes, biological food preservation, and control of food-borne biofilms are thoroughly investigated.

\section{Definition of Postbiotics}

According to the definition of postbiotics, they are metabolites produced by the bacteria living in the intestine and probiotic bacteria in fermented foods $[15,16]$. Many terms have been used for metabolites produced by probiotics, for example, biogenic, supernatant, abiotic, metabolic, pseudobiotic, and postbiotic [16]. Postbiotic are very common among these terms, and the word postbiotic is mostly used [17]. In the fermentation process, probiotic cells utilize dietary fibers (prebiotics) and frequently produce a wide range of postbiotics [18]. Today, these compounds are also being producing by laboratory methods. These methods include Thermal Treatment (TT), High Pressure (HP), Formalin Inactivation (FI), Ultraviolet (UV), Ionizing Radiation (IR), and sonication [5]. Postbiotics include three major components of inactivated microbial cells (cell wall), cell fractions (Teichoic acid), and cell metabolites (enzymes, shortchain fatty acids, bacteriocins, and organic acids) [18, 19], which, if consumed in sufficient quantities, possess health effects. Postbiotics have positive properties such as definitive chemical structure, safety profile, and longer shelf life, in addition to possessing immunemodulatory, anti-inflammatory, antioxidant, anti-obesity, anti-hypertensive, cholesterollowering, and antiproliferative properties $[16,20]$. There have been many studies on the beneficial effects of postbiotics (Table 1).

Table 1. Some important biological activities of postbiotics.

\begin{tabular}{|c|c|c|c|c|c|}
\hline Probiotic strains & $\begin{array}{c}\text { Derived } \\
\text { postbiotics }\end{array}$ & $\begin{array}{c}\text { Activation } \\
\text { method }\end{array}$ & Type of study & Biological activity & References \\
\hline Lactobacillus rhamnosus & $\begin{array}{l}\text { Cell-free } \\
\text { Supernatant }\end{array}$ & $\mathrm{UV}^{*}$ & $\begin{array}{l}\text { Animal model } \\
\text { (Mouse, pig) }\end{array}$ & $\begin{array}{ll}\text { Significant } & \text { reduction in } \\
\text { symptoms } & \text { of necrotic } \\
\text { enteritis } & \end{array}$ & [21] \\
\hline $\begin{array}{l}\text { Lactobacillus paracasei, } \\
\text { Lactobacillus casei }\end{array}$ & $\begin{array}{l}\text { Cell } \\
\text { Inactivated }\end{array}$ & $\mathrm{TT}^{* *}$ & In vitro & Immune system modulator & [22] \\
\hline Lactobacillus rhamnosus GG & $\begin{array}{l}\text { Cell-free } \\
\text { Supernatant }\end{array}$ & TT & $\begin{array}{l}\text { Human muscle } \\
\text { cell line }\end{array}$ & Anti-inflammatory & [23] \\
\hline $\begin{array}{l}\text { Lactobacillus bulgaricus, } \\
\text { Lactobacillus thermophiles }\end{array}$ & $\begin{array}{l}\text { Cell-free } \\
\text { Supernatant }\end{array}$ & TT & In vitro & $\begin{array}{l}\text { Protective role of Intestinal } \\
\text { cells }\end{array}$ & [24] \\
\hline Lactobacillus rhamnosus MD & $\begin{array}{l}\text { Cell-free } \\
\text { Supernatant }\end{array}$ & UV & In vitro & Decreased cell proliferation & [25] \\
\hline $\begin{array}{ll}\text { Lactobacillus } & \text { fermentum } \\
\text { BGHV110 TT } & \\
\end{array}$ & $\begin{array}{l}\text { Lysed cell } \\
\text { suspension }\end{array}$ & TT & In vivo & Protect the liver & [26] \\
\hline Bifidobacterium pomilus SE5 & $\begin{array}{l}\text { Inactivated } \\
\text { cell }\end{array}$ & TT & $\begin{array}{l}\text { Animal model } \\
\text { (Fish) }\end{array}$ & $\begin{array}{l}\text { Inhibition the growth of } \\
\text { pathogenic germs in the fish } \\
\text { intestines }\end{array}$ & [21] \\
\hline $\begin{array}{l}\text { Lactobacillus plantarum I- } \\
\text { UL4 }\end{array}$ & Bacteriocin & Not determined & $\begin{array}{l}\text { Animal model } \\
\text { (Fish) }\end{array}$ & $\begin{array}{l}\text { Inhibition of the growth of } \\
\text { Aeromonas hydrophila }\end{array}$ & [27] \\
\hline Lactobacillus plantarum & $\begin{array}{l}\text { Cell-free } \\
\text { Supernatant }\end{array}$ & UV & In vitro & Increased apoptosis & [28] \\
\hline
\end{tabular}

*UV, Ultraviolet; ${ }^{* *}$ TT, Thermal Treatment.

Also, given their good antimicrobial effect, they are a promising alternative to antibiotics $[5,29]$. Some studies have reported the translocation of probiotics from gut lumen (which might be pre-mature, inflamed, and/or leaky) to the bloodstream and from there into vital organs, which could trigger systemic infections. On the other hand, postbiotics are properly absorbed and metabolized and possess high stability, easy transportation, and significant signaling potential with various tissues and organs. Due to their unique properties (shelf life up to 5 years, non-toxicity, facile transportation, and low-cost maintenance) $[14,30]$, 
postbiotics can be used as a worthy antimicrobial compound to prevent food spoilage in the food industry $[19,31]$.

\section{Postbiotics and Food Safety}

The use of specific microorganisms (probiotics) to increase shelf life and prevent microbial spoilage of foods and use their associated antimicrobial metabolites (organic acids, peptides, hydrogen peroxide, proteins, vitamins, and bacteriocins) has a long history in the food industry. Despite the many advantages of using lactic acid-producing bacteria over antibiotics and chemical additives, there are many challenges in using these bacteria [32, 33]. An example in this regard includes the maintenance and use of live probiotics. Consumption of foods containing live probiotic bacteria in some cases can lead to clinical problems, particularly for people of different ages and physical conditions, as well as in people with weakened immune systems $[34,35]$. These include people with Crohn's disease, pregnant women, the elderly, and infants. Therefore, the use of live probiotics in the mentioned cases may be associated with serious health problems [36, 37]. Another important challenge in this field is the emergence of resistance to conventional employed antibiotics and the possibility of transmitting resistance genes to pathogenic organisms located in the host intestine [21, 38]. It is noteworthy to state that there are also opportunistic pathogenic bacteria in the intestinal microbiome, in which the acquisition of antibiotic resistance could be associated with serious problems [39]. Also, a piece of evidence suggests the presence of antibiotic-resistant species in food production processes. These bacteria's resistance profile indicates that infants are more sensitive to antibiotics compared to older age groups [40]. Other notable challenges and limitations are related to producing and maintaining live bacteria with beneficial performance. In the industry, most of the probiotics belong to the Lactobacillaceae family, which are non-spores and very sensitive to adverse environmental conditions, such that they lose their optimal performance over time and storage [41, 42]. On the other hand, providing the appropriate platform to enable a continuous cold chain from production to consumption often requires high costs [41]. In the food industry, some dairy foods or beverages as a carrier system for probiotics are common $[43,44]$. Due to the high cost of storing probiotics and the clinical problems that live probiotics cause, using non-living forms of probiotics (postbiotics) is a good solution [31, 45]. Postbiotics enhance food safety by possessing an antimicrobial role (preservation and packaging of food, control and elimination of food-borne pathogen biofilms, and preventing the growth of spoilage microorganisms) [46, 47]. Of course, postbiotics' antimicrobial role in the food industry depends on factors such as the strain of postbiotics' parent live cells, the type and concentration of postbiotics, the type of food model, and the characteristics of the food matrix. Here we discuss the antimicrobial mechanism of postbiotics to inhibit food spoilage and pathogenic microbes.

\subsection{The antimicrobial roles of postbiotics.}

One of the most important effects of postbiotics in the food industry involves using inhibiting food spoilage microbes. The fundamental portion of postbiotics' antimicrobial properties is due to the presence of organic acids, bacteriocins, peptides, fatty acids, and hydrogen peroxide compounds (Table 2). 


\begin{tabular}{|c|c|c|c|c|c|c|}
\hline $\begin{array}{l}\text { Probiotic } \\
\text { strain (s) }\end{array}$ & $\begin{array}{l}\text { Derived } \\
\text { postbiotic }\end{array}$ & Pathogen & $\begin{array}{l}\text { Antimicrobia } \\
\text { I mechanism }\end{array}$ & $\begin{array}{l}\text { Food model or } \\
\text { culture medium }\end{array}$ & $\begin{array}{l}\text { Method for measuring } \\
\text { antimicrobial activity }\end{array}$ & Reference \\
\hline $\begin{array}{l}\text { Lactobacillus } \\
\text { reuteri, Ent } \\
\text { erococcus } \\
\text { faccium, L. } \\
\text { acidophilus, } \\
\text { Pediococcus } \\
\text { acidilactici } \\
\end{array}$ & $\begin{array}{l}\text { Cell-free } \\
\text { supernatant }\end{array}$ & $\begin{array}{l}\text { Clostridium } \\
\text { perfringens }\end{array}$ & $\begin{array}{l}\text { Peptides (By } \\
\text { creating } \\
\text { cavities in the } \\
\text { bacterial cell } \\
\text { membrane) }\end{array}$ & Chicken & $\begin{array}{l}\text { Infected by kinematic } \\
\text { analysis using peptide } \\
\text { embodiment of poultry } \\
\text { meat (food model) }\end{array}$ & [48] \\
\hline $\begin{array}{l}\text { L. acidophilus } \\
\text { LA5, L. casei } \\
431, \\
\text { L.salivarius } \\
\text { (Ls-BU2) }\end{array}$ & $\begin{array}{l}\text { Cell-free } \\
\text { supernatant }\end{array}$ & $\begin{array}{l}\text { Listeria } \\
\text { monocytogenes }\end{array}$ & $\begin{array}{l}\text { Organic acid } \\
\text { (by acidifying } \\
\text { the cell } \\
\text { cytoplasm) }\end{array}$ & Ground meat & Agar-disk diffusion & [49] \\
\hline $\begin{array}{l}\text { Lactobacillus } \\
\text { plantarum }\end{array}$ & $\begin{array}{l}\text { Cell-free } \\
\text { supernatant }\end{array}$ & $\begin{array}{l}\text { Shigella } \\
\text { dysenterie }\end{array}$ & $\begin{array}{l}\text { Organic acid } \\
\text { (lactic acid } \\
\text { and acetic } \\
\text { acid), } \\
\text { Bacteriocin } \\
\text { (By affecting } \\
\text { cell wall } \\
\text { peptides) }\end{array}$ & $\begin{array}{l}\text { Muller Hinton } \\
\text { Agar }\end{array}$ & $\begin{array}{l}\text { The good diffusion } \\
\text { method }\end{array}$ & {$[50]$} \\
\hline $\begin{array}{l}\text { Lactobacillus } \\
\text { plantarum }\end{array}$ & $\begin{array}{l}\text { Cell-free } \\
\text { supernatant }\end{array}$ & $\begin{array}{l}\text { Listeria } \\
\text { monocytogenes }\end{array}$ & $\begin{array}{l}\text { Organic acid } \\
\text { (by acidifying } \\
\text { the cell } \\
\text { cytoplasm) }\end{array}$ & $\begin{array}{l}\text { Pasteurized milk } \\
\text { and Ground meat }\end{array}$ & $\begin{array}{l}\text { The well diffusion } \\
\text { method }\end{array}$ & [49] \\
\hline $\begin{array}{l}\text { Lactobacillus } \\
\text { salivarius (Ls } \\
-B U 2)\end{array}$ & $\begin{array}{l}\text { Cell-free } \\
\text { supernatant }\end{array}$ & Escherichia coli & $\begin{array}{l}\text { Organic acid } \\
\text { and } \\
\text { bacteriocins } \\
\text { (by acidifying } \\
\text { the cell } \\
\text { cytoplasm) }\end{array}$ & $\begin{array}{l}\text { Muller Hinton } \\
\text { Agar }\end{array}$ & Agar-disk diffusion & [51] \\
\hline
\end{tabular}

\subsubsection{Organic acid.}

Organic acids are compounds appropriate as antimicrobial agents [52]. Organic acids are known as one of the key postbiotics. Lactic acid (produced by bacterial fermentation processes) is available in two isomers, $\mathrm{L}$ and $\mathrm{D}$, which effectively inhibits pathogenicity [53]. Also, citric acid and acetic acid inhibit the growth of pathogens by creating an acidic environment. Among organic acids, lactic acids ( $\mathrm{pka}=3.86)$ and acetic acids (pka=4.76) inhibit the growth of pathogens by reducing $\mathrm{pH}$ value under in vitro or/and in vivo conditions [54]. The inhibitory effect of organic acids is related to their effect on bacterial cell membranes. The main mechanisms here involve lowering the intracellular $\mathrm{pH}$ and membrane integrity [55]. The antimicrobial activity of organic acids can be linked in two ways. Acidification of cellular cytoplasm and prevention or/and energy production regulation [54] (Figure 2).

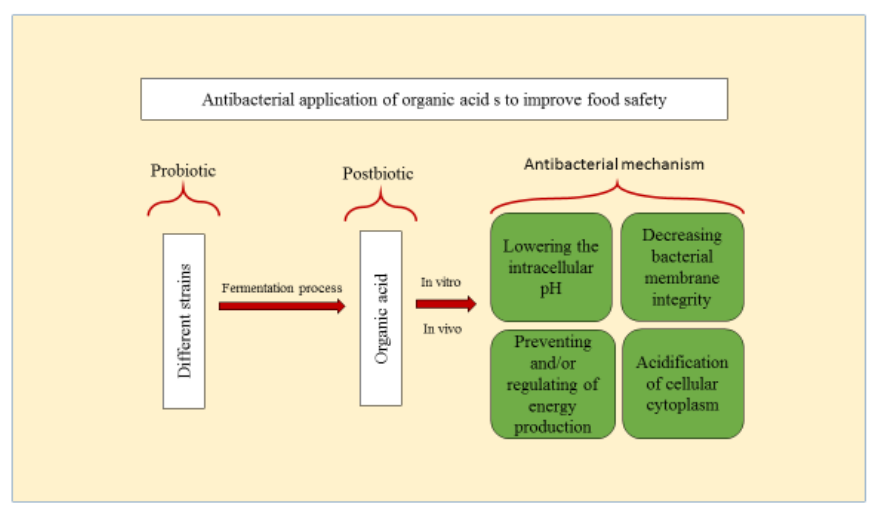

Figure 2. Organic acids are an example of postbiotics that are mainly produced from different probiotic types through the fermentation process. Organic acids have good antimicrobial effects through special mechanisms 
In a study, Chang-Hui Hul et al. (2019) isolated organic acids (lactic acid, acetic acid, tartaric acid, malic acid, and citric acid) produced by three strains of Lactobacillus plantarum $(P 1, S 11$, and $M 7)$ and investigated the antimicrobial effect of these acids against pathogenic bacteria (Escherichia coli and Salmonella). They found that the organic acids secreted by $L$. plantarum strains prevent the development of pathogenic bacteria. The antibacterial effects of organic acids are exerted by reducing the $\mathrm{pH}$ and acidification of bacteria's cell membrane. Among organic acids, lactic acid and acetic acid have very strong antibacterial activities. Given these results, this is a potential approach to developing new antimicrobial agents for extensive use in the food sector for biopreservation, which involves mixing different organic acids [56].

\subsubsection{Bacteriocins.}

Bacteriocins are peptides or proteins with antimicrobial activity and are produced by various bacteria, such as Archaebacteria and Eubacteria [55]. Bacteriocins have a high antimicrobial activity that has been used for thousands of years by humans in fermented foods [57]. Bacteriocins are divided according to size, mechanism of action, and inhibitory spectrum. Bacteriocins have many beneficial effects, such as inhibiting gastrointestinal pathogens' growth and development and being heat- and pH-resistant. According to the study's results, bacteriocins' main activity is in the bacterial cytoplasmic membrane [58]. The antimicrobial mechanism of bacteriocins is directly related to their effects on bacterial peptides' structure and function and their inhibitory activities on spores and pore formation on pathogenic cell membranes (Figure 3).

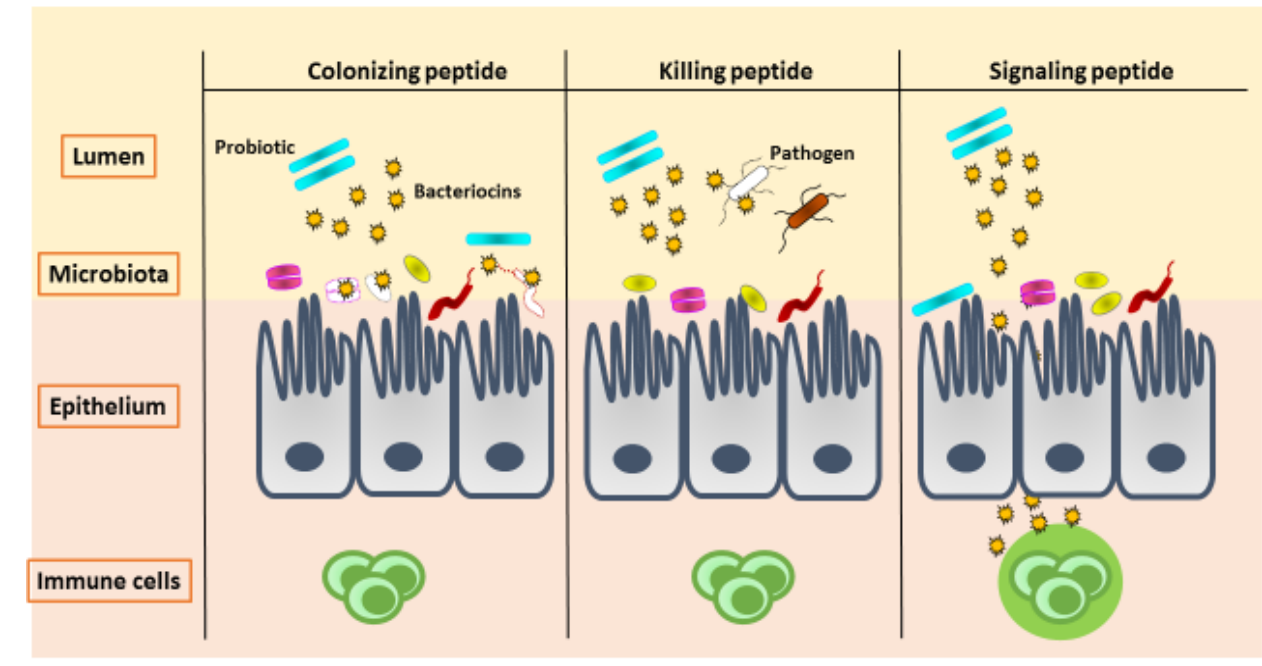

Figure 3. Main mechanisms of bacteriocins. Bacteriocins may action as colonizing peptides, assisting the race of a probiotic with the gut resident microbiota; they may act as killing peptides, straightly removing pathogen germs; or they may assist as signaling peptides, signaling other microorganisms or the host immune system.

In a study, Yao Wang (2019) used bacteriocins from Lactobacillus plantarum LPL-1 isolated from fish against Listeria monocytogenes. As a result, it was found that the bacteriocins could inhibit the growth of $L$. monocytogenes by acidifying the cell membrane of $L$. monocytogenes and creating pores in the bacterial membrane [59]. In another study, Sam Woong Kim (2020) and colleagues assessed the effect of bacteriocins produced by Lactobacillus taiwanensis against Salmonella gallinarum and Escherichia coli. Resultantly, it was observed that the bacteriocin produced by L. taiwanensis could inhibit bacterial growth through the lysis of the membrane of pathogenic bacteria and thus damage their protein 
structure. Based on the results of the mentioned studies, bacteriocins can be used as a tool to inhibit the bacteria that cause food spoilage.

\subsubsection{Fatty acids.}

Fatty acids and their derivatives are a good alternative to antibiotics. The antimicrobial activity of fatty acids has been identified for more than 100 years. Fatty acids are formed from a saturated and unsaturated carbon chain attached to a carboxylic (hydrophilic) group [60, 61]. Fatty acids are also recognized as potential postbiotics that have meaningful antimicrobial properties. Long-chain fatty acids, such as Eicosapentaenoic acid (EPA), act against Grampositive bacteria [61]. Among other fatty acids, lauric and meristic acids are highly active against microbes' growth and development [62]. Antimicrobial mechanisms of fatty acids on bacteria include increasing membrane permeability, lysing the cell, disrupting the electron transport chain, disrupting enzymes' structure and activity, and inducing morphological/functional changes on sensitive components such as proteins [63]. Bruna Higashi and colleagues (2020) explored the effect of fatty acids produced by Lactobacillus acidophilus, L. fermentum, L. paracasei ATCC 335, and L. brevis against Klebsiella oxytoca. They observed that fatty acids produced by the probiotic bacteria inhibit the growth of these bacteria through lysing the cell wall of Klebsiella oxytoca.

\subsubsection{Peptides.}

Microorganisms produce antimicrobial peptides. Peptides destroy microbes through pleiotropic (multiple actions) mechanisms, such as microbial membrane degradation and macromolecule synthesis inhibition [64]. Antimicrobial peptides are divided into ribosomal and non-ribosomal types. Peptides produced by the bacteria are ribosomal [65] and show strong antimicrobial activity in vitro by disrupting microbial membranes [66]. Peptides are commonly present in all bacteria. As mentioned, some peptides' main target is the cell membrane, while for others, it is the cytoplasm and sensitive structures of bacteria. Antimicrobial mechanisms of the peptides include (a) creating acidity in the bacterial cell membrane, (b) creating physical holes that leak cellular content, (c) activating lethal processes such as inducing hydrolases that have detrimental effects on the cell-wall, (d) and damaging sensitive intracellular components of the microbes [67].

Brittany Forkus et al. (2017) used peptides from E. coli Nissle 1917 against Salmonella enterica isolated from the turkey digestive tract. In this study, it was found that the antimicrobial peptides produced by E. coli Nissle 1917 inhibit the growth of Salmonella enterica by damaging the cell wall structure. Vadakedath Nithya (2012) evaluated the effect of antibacterial peptides produced by Bacillus subtilis against L. monocytogenes and E. coli. In this study, it was found that peptides produced by Bacillus subtilis inhibit bacteria's growth by damaging sensitive structures. These observations suggest the possibility of using antimicrobial peptides produced by probiotics in food preservation.

\subsubsection{Hydrogen peroxide.}

Hydrogen peroxide is mainly produced by all bacteria but is generally visible in aerobic cultures of catalase-negative bacteria and is the major metabolite of lactic acid bacteria [68]. Inhibitory and antibacterial effects depend on various factors, the most important of which is the concentration of hydrogen peroxide $\left(\mathrm{H}_{2} \mathrm{O}_{2}\right)$, which could exert antibacterial effects 
depending on its concentration. Some factors, such as selected bacterial strains and environmental conditions (temperature and $\mathrm{pH}$ ), can also influence bacterial concentration [69]. The antimicrobial effects of $\mathrm{H}_{2} \mathrm{O}_{2}$ are related to its potent oxidizing functions on the bacterial cell and the damage to cytoplasmic protein structures [70].

Mahsa Abbasi et al. (2020) investigated the effects of Lactobacillus acidophilus, $L$. rhamnosus Bifidobacterium longum, and $B$. infantis do bacterium breve against methicillinresistant Staphylococcus aureus (MRSA) in vitro. In this study, it was found that probiotic bacteria could prevent Staphylococcus aureus' growth through hydrogen peroxide production. Based on such studies, it can be concluded that postbiotic compounds, such as hydrogen peroxide, can be used as a suitable alternative to antibiotics against pathogenic bacteria and food spoilage.

\subsubsection{Vitamins.}

Probiotic bacteria in the host gut and the food matrix produce large amounts of vitamins [71]. Although the production of vitamins by probiotic bacteria in the intestine is very low, its production significantly increases in the food matrix, especially in dairy products [72]. By examining the antimicrobial role of probiotic bacteria, it was revealed that the vitamins produced by these bacteria play an important role in inhibiting harmful microbes. In laboratory models, vitamin compounds are produced by lysing probiotic bacteria (Lactobacillus plantarum) [73]. Vitamin $\mathrm{C}$ has a greater antimicrobial role than others. Vitamin $\mathrm{C}$ increases bacterial cell membrane lipids' acidity, resulting in the lysis of cell membrane and bacterial cell wall [74]. Due to the valuable antimicrobial properties of postbiotic compounds, these compounds can be used in the food industry in various ways to preserve food and increase food shelf life.

\section{Postbiotic Application in Food}

Preservation of food by using postbiotic compounds is called food-biopreservation [31]. This is a new method in the food industry in which most perishable foods can be stored.

\subsection{Biopreservation of dairy products.}

In the past, dairy products were used as a vehicle to boost beneficial intestinal microbiota (probiotics). However, spoilage of dairy compounds by external factors could negatively impact the survival of probiotic strains throughout processing and storage [75]. The use of postbiotics in dairy products is a new way to improve the safety of dairy products. Of course, factors involved in the performance of postbiotics are very important in food preservation. Regarding safety, preparing postbiotic compounds in a Mannitol Salt Agarculture medium will not be interesting compared to industrially prepared postbiotics. For example, the results by Mehran Moradi et al. have shown that MRS-prepared postbiotics might have considerable negative effects on the sensory features of the product and affect overall consumer acceptance. Due to the whiteness, fluidity, and opacity of milk, several additives could lead to alterations in the color and form of the milk [49]. A recent study aimed to use postbiotics prepared from three probiotic strains in milk as antifungal agents to prevent fungal spoilage growth in semi-hard cheese and sour cream [76]. They found that postbiotics could considerably reduce the fungal population in cheese, without any impacts on sensory uptake. 
Recently, it has been suggested that postbiotics can be used as an antimicrobial compound in spray form to inhibit harmful microbes [31].

\subsection{Biopreservation of meat products.}

The decay of meat is mostly caused by bacteria [77]. The most important of these bacteria are Clostridium perfringens and different genera of the Enterobacteriaceae family. These bacteria cause undesirable organoleptic changes in meat, making it unattractive for the consumer [78]. As antimicrobial agents in preserving the products of meat, postbiotic compounds could be directly applied to the product through coating and spraying techniques. For example, in minced meat, the spray method is preferred, while the coating is suggested for meat fillets. Several experiments have shown the advantageous effects of postbiotic compounds for preserving meat in the refrigerator. In a recent study, the direct addition of Bifidobacterium lactis $B b-12$ to Bifidobacterium caused the minced meat to survive for up to 3 months at $4{ }^{\circ} \mathrm{C}$ [79]. Lactobacillus rhamnosus EMCC 1105 postbiotics at a concentration of $100 \mathrm{mg} / \mathrm{g}$ killed Clostridium perfringens on minced chicken on the fourth day of storage at $6^{\circ}$. Of course, the amount of antimicrobial activity of postbiotic compounds depends on the type of postbiotic compound [80]. Among postbiotic compounds, bacteriocins have a very strong antimicrobial effect. In this regard, a study investigated the antimicrobial effects of postbiotics derived from three probiotics (Lactobacillus acidophilus LA5, Lactobacillus casei 431, and Lactobacillus salivarius) on Listeria monocytogenes in minced meat and Luria Bertani broth. It was observed that this postbiotic compound could inhibit the growth of L. monocytogenes and prevent the spoilage of minced meat and Luria Bertani broth. Further identification of postbiotic compounds revealed that such antimicrobial effect of postbiotics is related to the presence of bacteriocins and organic acids $[49,81]$. Therefore, the use of postbiotic compounds can be a new method in the preservation of meat products.

\subsection{Application of postbiotics in the removal of biofilms.}

Biofilms are a collection of one or more types of microorganisms that can grow at different levels. A biofilm is a complex microbial community enclosed within a polysaccharide or protein matrix [82]. Biofilms can be caused by microorganisms such as fungi and bacteria. Both gram-positive and gram-negative bacteria enjoy such ability [83]. Bacterial resistance in the biofilm phase to antimicrobials is a major global issue. The formation stages include a reversible and irreversible attachment to the surface and microclone formations with exopolysaccharide production [84]. In the food industry, irreversible biofilms and colony constituents are very important, and control over them is essential for food safety [85]. Biofilms formed in the food industry are more resistant to cleaning and disinfection processes. Listeria monocytogenes, Yersinia enterocolitica, Campylobacter jejuni, Staphylococcus aureus, and Bacillus cereus are important biofilm-forming bacteria in the food industry [86]. Many methods have been used to control and destroy the biofilms formed by bacteria. Using postbiotics to kill biofilms is a new approach. In addition to having antimicrobial properties, postbiotics also can destroy biofilms formed by the bacteria. In recent years, the effect of postbiotics on the elimination of bacterial biofilms has been studied, which have yielded positive results [87]. In one study, postbiotics' antibiofilm effect was derived from the probiotic bacteria Lactobacillus acidophilus LA5, Lactobacillus casei 431, and Lactobacillus salivarius on a biofilm formed by L. monocytogenes on the polystyrene surfaces was observed. It was 
demonstrated that postbiotics destroy biofilm formation. The authors established that the presence of bacteriocin- and organic acid-based postbiotics are the main cause for the biofilm reduction of L. monocytogenes. Therefore, postbiotics can be used as a tool to control and eliminate biofilm formation by bacteria in the food industry [49].

There are some factors that may affect the performance of postbiotics and prevent the proper functioning of postbiotics.

\section{The Effect of Food Factors on the Performance of Postbiotics}

Some factors affect the performance of postbiotics, which include internal or external factors. Internal factors and external factors are associated with all food matrix compounds and all factors in the food storage environment, respectively [49]. The results of investigations have demonstrated that these factors significantly affect the nature, structure, and functions of postbiotics, which are necessary considering the optimal condition in the production and applying postbiotics in the food matrix or/and pharmaceutical products.

\subsection{Internal factors.}

Various compounds in food can affect the function of postbiotics. The interaction between active metabolites of postbiotic and specific food substances (endogenous microflora, enzymes, carbohydrates, proteins, and fats) can inhibit metabolites' function [31]. For example, proteolytic enzymes in food may interfere with the activity of postbiotic compounds. Proteolytic enzymes can break down postbiotic protein compounds and prevent their function. These enzymes may either be in the food or be secreted by the proteolytic bacteria in the food. The most important enzymes are pepsin, trypsin, chymotrypsin, papain, and proteinase K. For example, if the proteinaceous postbiotics are applied, the protease enzyme breaks down the protein and prevents the postbiotic effect. Therefore, proteolytic enzymes are one of the factors that should be considered with regard to postbiotic dysfunctions [88, 89]. However, there are no reports of synergistic and antagonistic activity of postbiotic mixtures with food compounds.

\subsection{External factors.}

Food $\mathrm{pH}$ can affect the antimicrobial activity of postbiotics. High acidity and alkaline foods can affect the function of postbiotics. There exists a specific scope for postbiotic activity. The $\mathrm{pH}$ range of 4 to 9 is the best range for postbiotic activity. Among the food models that have used postbiotics to control the microbes, pasteurized milk and ground meat had a good $\mathrm{pH}$, and there were no disturbances in the function of postbiotics [49]. Heat is also an external factor that can affect the performance of postbiotics. Heat can affect the antimicrobial activity of postbiotics. The antimicrobial effect of postbiotic compounds is reduced at $30^{\circ} \mathrm{C}$ for 30 minutes and then at $121^{\circ} \mathrm{C}$ for 15 minutes [90]. Therefore, the food heating process also may play a significant role in the activity of postbiotics. Suppose postbiotic compounds are applied in functional foods formulation. In that case, it is vital to maintain the temperature factor at an optimum level during processing and preparing conditions.

\section{Microencapsulation of Postbiotics}

Protection of postbiotics against adverse environments, including antimicrobial agents, chemicals, active oxygen in case of obligatory anaerobic microbes, bile salts, and high acidity, could be performed through employing microencapsulation methods. Also, through utilizing 
techniques such as fluidized bed drying, spray cooling, extrusion, chilling, molecular inclusion, spray drying, co-crystallization, and co-accretion, it would be possible to develop the processing of a forming capsule [91, 92]. Choosing the technique of interest is dependent on the material type, application, and release mechanism. Compounds such as carbohydrates, proteins, and lipids can be used to microencapsulate postbiotics [93]. Materials used for the microencapsulation of postbiotics should be non-toxic, highly soluble, heat-resistant, oxygenpermeable through the food matrix, acid-resistant, and unstable at $\mathrm{pH}$ above $6[94,95]$. In the process of encapsulation of postbiotics, a biocompatible matrix should be used to encapsulate postbiotics against factors such as $\mathrm{pH}$ and high temperature. The biocompatible matrix acts as a semi-permeable membrane and allows the transfer of postbiotics in two directions. Studies in recent years on postbiotics' encapsulation have shown that encapsulation is a suitable method to protect these compounds against inappropriate factors. In this regard, Le et al. (2019) encapsulated postbiotic (bacteriocin) produced by Lactobacillus plantarum isolated from Vietnamese fermented yogurt in alginate-gelatin (ALG-GEL). Also, its antimicrobial effects in the presence of factors including incubation temperature, moderate $\mathrm{pH}$, and surfactants (Ethylene diamine tetraacetic acid (EDTA), sodium dodecyl sulfate (SDS), and twin) against five indicator organisms, such as Escherichia coli, Salmonella, staphylococcus aureus, Listeria monocytogenes, and Bacillus subtilis were evaluated in meat. They observed that encapsulating postbiotics in the presence of these factors could prevent the spoilage of pork by pathogens [91]. It seems that the microencapsulation of postbiotics can be a good way to protect postbiotics. Using microencapsulation technology, postbiotics could be used in foods exposed to high temperatures and low $\mathrm{pH}$ (e.g., vegetables) [96].

\section{Conclusions}

Currently, novel factors are constantly threatening food safety, increasing with changes in food production, distribution, consumption, and the changes in the environment, emerging pathogens, and antimicrobial resistance. Food safety hazards are increasing unprecedentedly, and strengthening food safety approaches is felt more than ever in all countries. The significance of food safety has been so much emphasized that the World Health Organization stated its slogan in 2015 to promote enhanced food safety from farm to plate. Food safety hazards include physical, chemical, and biological, among which biological hazards are the most important. Bacteria are very important in causing diseases and food spoilage, and thus preventing them is a top priority. In recent years, new approaches have been used to control the bacteria, including the use of probiotics and postbiotics. Postbiotics' main antimicrobial activities are associated with bioactive components, such as organic acids, bacteriocins, fatty acids, peptides, hydrogen peroxide, and vitamins. Due to their unique features (safe profile and stability in the manufacturing and storage conditions), postbiotics can be used as a promising tool to prevent the growth of potential food-borne pathogens and promote host health status. Further experiments are required to evaluate the biological role of postbiotics in the food industry for improving food safety and quality.

\section{Funding}

This research received no external funding. 


\title{
Acknowledgments
}

The authors would like to express their thanks to the Research vice-chancellor of Tabriz University of Medical Sciences for this study's financial support.

\section{Conflicts of Interest}

\author{
The authors declare no conflict of interest.
}

\section{References}

1. Ayivi, R.D.; Gyawali, R.; Krastanov, A.; Aljaloud, S.O.; Worku, M.; Tahergorabi, R.; da Silva, R.C.; Ibrahim, S.A. Lactic Acid Bacteria: Food Safety and Human Health Applications. Dairy 2020, 1, 202-232, https://doi.org/10.3390/dairy1030015.

2. Nardi, V.A.M.; Teixeira, R.; Ladeira, W.J.; de Oliveira Santini, F. A meta-analytic review of food safety risk perception. Food Control 2020, 112, https://doi.org/10.1016/j.foodcont.2020.107089.

3. Jalava, K. First respiratory transmitted food borne outbreak? International journal of hygiene and environmental health 2020, 226, https://doi.org/10.1016/j.ijheh.2020.113490.

4. Sutherland, C.; Sim, C.; Gleim, S.; Smyth, S.J. Consumer Insights on Canada's Food Safety and Food Risk Assessment Systems. Journal of Agriculture and Food Research 2020, 2, https://doi.org/10.1016/j.jafr.2020.100038.

5. Rad, A.; Abbasi, A.; Javadi, A.; Pourjafar, H.; Javadi, M.; Khaleghi, M. Comparing the microbial quality of traditional and industrial yoghurts. Biointerface Research in Applied Chemistry 2020, 10, 6020-6025, https://doi.org/10.33263/briac104.020025.

6. de Freitas, R.S.G.; da Cunha, D.T.; Stedefeldt, E. Food safety knowledge as gateway to cognitive illusions of food handlers and the different degrees of risk perception. Food research international 2019, 116, 126134, https://doi.org/10.1016/j.foodres.2018.12.058

7. Peivasteh-Roudsari, L.; Pirhadi, M.; Karami, H.; Tajdar-oranj, B.; Molaee-Aghaee, E.; Sadighara, P. Probiotics and food safety: an evidence-based review. Journal of Food Safety and Hygiene 2019, 5, 50-50, https://doi.org/10.18502/jfsh.v5i1.3878.

8. Odeyemi, O.A.; Sani, N.A.; Obadina, A.O.; Saba, C.K.S.; Bamidele, F.A.; Abughoush, M.; Asghar, A.; Dongmo, F.F.D.; Macer, D.; Aberoumand, A. Food safety knowledge, attitudes and practices among consumers in developing countries: An international survey. Food research international 2019, 116, 13861390, https://doi.org/10.1016/j.foodres.2018.10.030.

9. Scognamiglio, V.; Arduini, F.; Palleschi, G.; Rea, G. Biosensing technology for sustainable food safety. TrAC Trends in Analytical Chemistry 2014, 62, 1-10, https://doi.org/10.1016/j.trac.2014.07.007.

10. Drewnowski, A. The economics of food choice behavior: why poverty and obesity are linked. In: Obesity treatment and prevention: new directions. Karger Publishers, Volume 73, 2012; pp. 95-112, https://doi.org/10.1159/000341303.

11. Flynn, K.; Villarreal, B.P.; Barranco, A.; Belc, N.; Björnsdóttir, B.; Fusco, V.; Rainieri, S.; Smaradóttir, S.E.; Smeu, I.; Teixeira, P. An introduction to current food safety needs. Trends in Food Science \& Technology 2019, 84, 1-3, https://doi.org/10.1016/j.tifs.2018.09.012.

12. Gaggia, F.; Di Gioia, D.; Baffoni, L.; Biavati, B. The role of protective and probiotic cultures in food and feed and their impact in food safety. Trends in food science \& technology 2011, 22, S58-S66, https://doi.org/10.1016/j.tifs.2011.03.003.

13. Abbasi A.; Aghebati-Maleki A.; Aghebati-Maleki L.; Yousefi M. Probiotic intervention as a potential therapeutic for managing gestational disorders and improving pregnancy outcomes. Journal of Reproductive Immunology 2021, 143,103244, https://doi.org/10.1016/j.jri.2020.103244.

14. Tomar, S.K.; Anand, S.; Sharma, P.; Sangwan, V.; Mandal, S. Role of probiotics, prebiotics, synbiotics and postbiotics in inhibition of pathogens. In: The Battle against Microbial Pathogens: Basic Science, Technological Advances and Educational Programs. Méndez-Vilas, A. Ed 2015; pp. 717-732.

15. Izuddin, W.I.; Loh, T.C.; Foo, H.L.; Samsudin, A.A.; Humam, A.M. Postbiotic L. plantarum RG14 improves ruminal epithelium growth, immune status and upregulates the intestinal barrier function in post-weaning lambs. Scientific reports 2019, 9, 1-10,| https://doi.org/10.1038/s41598-019-46076-0.

16. Rad, A.H.; Aghebati-Maleki, L.; Kafil, H.S.; Abbasi, A. Molecular mechanisms of postbiotics in colorectal cancer prevention and treatment. Critical Reviews in Food Science and Nutrition 2020, 1-17, https://doi.org/10.1080/10408398.2020.1765310.

17. Abbasi A.; Ghasempour Z.; Sabahi S.; Kafil HS.; Hasannezhad P.; Rahbar Saadat Y.; Shahbazi N. The biological activities of postbiotics in gastrointestinal disorders. Critical Reviews in Food Science and Nutrition 2021, 1-22, https://doi.org/10.1080/10408398.2021.1895061. 
18. Homayouni Rad, A.; Aghebati Maleki, L.; Samadi Kafil, H.; Abbasi, A. Postbiotics: A novel strategy in food allergy treatment. Critical Reviews in Food Science and Nutrition 2020, 61, 1-8, https://doi.org/10.1080/10408398.2020.1738333.

19. Yordshahi, A.S.; Moradi, M.; Tajik, H.; Molaei, R. Design and preparation of antimicrobial meat wrapping nanopaper with bacterial cellulose and postbiotics of lactic acid bacteria. International Journal of Food Microbiology 2020, 321, https://doi.org/10.1016/j.ijfoodmicro.2020.108561.

20. Aguilar-Toalá, J.; Garcia-Varela, R.; Garcia, H.; Mata-Haro, V.; González-Córdova, A.; Vallejo-Cordoba, B.; Hernández-Mendoza, A. Postbiotics: An evolving term within the functional foods field. Trends in Food Science \& Technology 2018, 75, 105-114, https://doi.org/10.1016/j.tifs.2018.03.009.

21. Fathi-zavoshti, H.; Douroud, N.; Shahbazi, N.; Abbasi, A. Evaluating the Role of Postbiotics as a New Generation of Probiotics in Health and Diseases. Journal of Ardabil University of Medical Sciences 2020, 19, 381-399, http://dx.doi.org/10.29252/jarums.19.4.381.

22. Sokol, H.; Pigneur, B.; Watterlot, L.; Lakhdari, O.; Bermúdez-Humarán, L.G.; Gratadoux, J.-J.; Blugeon, S.; Bridonneau, C.; Furet, J.-P.; Corthier, G. Faecalibacterium prausnitzii is an anti-inflammatory commensal bacterium identified by gut microbiota analysis of Crohn disease patients. Proceedings of the National Academy of Sciences 2008, 105, 16731-16736, https://doi.org/10.1073/pnas.0804812105.

23. Cicenia, A.; Santangelo, F.; Gambardella, L.; Pallotta, L.; Iebba, V.; Scirocco, A.; Marignani, M.; Tellan, G.; Carabotti, M.; Corazziari, E.S. Protective role of postbiotic mediators secreted by Lactobacillus rhamnosus GG versus lipopolysaccharide-induced damage in human colonic smooth muscle cells. Journal of Clinical Gastroenterology 2016, 50, S140-S144, https://doi.org/10.1097/MCG.0000000000000681.

24. Zeng, J.; Jiang, J.; Zhu, W.; Chu, Y. Heat-killed yogurt-containing lactic acid bacteria prevent cytokineinduced barrier disruption in human intestinal Caco-2 cells. Annals of microbiology 2016, 66, 171-178, https://doi.org/10.1007/s13213-015-1093-2.

25. Sharma, M.; Chandel, D.; Shukla, G. Antigenotoxicity and cytotoxic potentials of metabiotics extracted from isolated probiotic, Lactobacillus rhamnosus MD 14 on Caco-2 and HT-29 human colon cancer cells. Nutrition and Cancer 2020, 72, 110-119, https://doi.org/10.1080/01635581.2019.1615514.

26. Kamilya, D.; Baruah, A.; Sangma, T.; Chowdhury, S.; Pal, P. Inactivated probiotic bacteria stimulate cellular immune responses of catla, Catla catla (Hamilton) in vitro. Probiotics and antimicrobial proteins 2015, 7, 101-106, https://doi.org/10.1007/s12602-015-9191-9.

27. Foo, H.; Loh, T.; Abdul Mutalib, N.; Rahim, R. The myth and therapeutic potentials of postbiotics. In: Microbiome and Metabolome in Diagnosis, Therapy, and Other Strategic Applications. Academic Press 2019; pp. 201-208.

28. Chuah, L.-O.; Foo, H.L.; Loh, T.C.; Alitheen, N.B.M.; Yeap, S.K.; Mutalib, N.E.A.; Rahim, R.A.; Yusoff, K. Postbiotic metabolites produced by Lactobacillus plantarum strains exert selective cytotoxicity effects on cancer cells. BMC complementary and alternative medicine 2019, 19, https://doi.org/10.1186/s12906-0192528-2.

29. Johnson, C.N.; Kogut, M.H.; Genovese, K.; He, H.; Kazemi, S.; Arsenault, R.J. Administration of a Postbiotic Causes Immunomodulatory Responses in Broiler Gut and Reduces Disease Pathogenesis Following Challenge. Microorganisms 2019, 7, https://doi.org/10.3390/microorganisms7080268.

30. Shigwedha, N. Probiotical cell fragments (PCFs) as "novel nutraceutical ingredients". Journal of Biosciences and Medicines 2014, 2, http://dx.doi.org/10.4236/jbm.2014.23007.

31. Rad AH.; Abbasi A.; Kafil HS.; Ganbarov K. Potential pharmaceutical and food applications of postbiotics: a review. Current pharmaceutical biotechnology 2020, 21, 1576-1587, https://doi.org/10.2174/1389201021666200516154833.

32. Kothari, D.; Patel, S.; Kim, S.-K. Probiotic supplements might not be universally-effective and safe: A review. Biomedicine \& Pharmacotherapy 2019, 111, 537-547,https://doi.org/10.1016/j.biopha.2018.12.104.

33. Rad, A.H.; Maleki, L.A.; Kafil, H.S.; Zavoshti, H.F.; Abbasi, A. Postbiotics as novel health-promoting ingredients in functional foods. Health Promotion Perspectives 2020, 10, 3-4, https://dx.doi.org/10.15171\%2Fhpp.2020.02.

34. Sartor, R. The potential mechanisms of action of rifaximin in the management of inflammatory bowel diseases. Alimentary pharmacology \& therapeutics 2016, 43, 27-36, https://doi.org/10.1111/apt.13436.

35. Homayouni Rad A.; Samadi Kafil H.; Fathi Zavoshti H.; Shahbazi N.; Abbasi A. Therapeutically Effects of Functional Postbiotic Foods. Clinical Excellence 2020 10, 33-52, http://ce.mazums.ac.ir/article-1-532en.html.

36. Devirgiliis, C.; Zinno, P.; Perozzi, G. Update on antibiotic resistance in food-borne Lactobacillus and Lactococcus species. Frontiers in Microbiology 2013, 4, https://doi.org/10.3389/fmicb.2013.00301.

37. Ogier, J.-C.; Serror, P. Safety assessment of dairy microorganisms: the Enterococcus genus. International journal of food microbiology 2008, 126, 291-301, https://doi.org/10.1016/j.ijfoodmicro.2007.08.017.

38. Mathur, S.; Singh, R. Antibiotic resistance in food lactic acid bacteria - a review. International journal of food microbiology 2005, 105, 281-295, https://doi.org/10.1016/j.ijfoodmicro.2005.03.008.

39. Gueimonde, M.; Sánchez, B.; de los Reyes-Gavilán, C.G.; Margolles, A. Antibiotic resistance in probiotic bacteria. Frontiers in microbiology 2013, 4, https://doi.org/10.3389/fmicb.2013.00202. 
40. Dash, G.; Raman, R.P.; Prasad, K.P.; Makesh, M.; Pradeep, M.; Sen, S. Evaluation of paraprobiotic applicability of Lactobacillus plantarum in improving the immune response and disease protection in giant freshwater prawn, Macrobrachium rosenbergii (de Man, 1879). Fish \& shellfish immunology 2015, 43, 167174, https://doi.org/10.1016/j.fsi.2014.12.007.

41. Sawada, D.; Sugawara, T.; Ishida, Y.; Aihara, K.; Aoki, Y.; Takehara, I.; Takano, K.; Fujiwara, S. Effect of continuous ingestion of a beverage prepared with Lactobacillus gasseri CP2305 inactivated by heat treatment on the regulation of intestinal function. Food Research International 2016, 79, 33-39, https://doi.org/10.1016/j.foodres.2015.11.032.

42. Rad, A.H.; Maleki, L.A.; Kafil, H.S.; Zavoshti, H.F.; Abbasi, A. Postbiotics as promising tools for cancer adjuvant therapy. Advanced Pharmaceutical Bulletin 2020, 11, 1-5, https://doi.org/10.34172/apb.2021.007.

43. Shafiei, R.; Delvigne, F.; Babanezhad, M.; Thonart, P. Evaluation of viability and growth of Acetobacter senegalensis under different stress conditions. International journal of food microbiology 2013, 163, 204213, https://doi.org/10.1016/j.ijfoodmicro.2013.03.011.

44. de Almada, C.N.; Almada, C.N.; Martinez, R.C.; Sant'Ana, A.S. Paraprobiotics: evidences on their ability to modify biological responses, inactivation methods and perspectives on their application in foods. Trends in food science \& technology 2016, 58, 96-114, https://doi.org/10.1016/j.tifs.2016.09.011.

45. Garcia-Varela, R.; Garcia, H.; Mata-Haro, V.; Vallejo-Cordoba, B. Postbiotics: an evolving term within the functional foods field. Trends in food science \& technology 2018, 75, 105-114, https://doi.org/10.1016/j.tifs.2018.03.009.

46. Moreirinha, C.; Vilela, C.; Silva, N.H.; Pinto, R.R.; Almeida, A.; Rocha, M.A.M.; Coelho, E.; Coimbra, M.A.; Silvestre, A.A.; Freire, C.S. Antioxidant and antimicrobial films based on brewers spent grain arabinoxylans, nanocellulose and feruloylated compounds for active packaging. Food Hydrocolloids 2020, 108, https://doi.org/10.1016/j.foodhyd.2020.105836.

47. Karimi, N.; Jabbari, V.; Nazemi, A.; Ganbarov, K.; Karimi, N.; Tanomand, A.; Karimi, S.; Abbasi, A.; Yousefi, B.; Khodadadi, E. Thymol, cardamom and Lactobacillus plantarum nanoparticles as a functional candy with high protection against Streptococcus mutans and tooth decay. Microbial pathogenesis 2020, 148, https://doi.org/10.1016/j.micpath.2020.104481.

48. Shanmugasundaram, R.; Markazi, A.; Mortada, M.; Ng, T.; Applegate, T.; Bielke, L.; Syed, B.; Pender, C.; Curry, S.; Murugesan, G. Research Note: Effect of synbiotic supplementation on caecal Clostridium perfringens load in broiler chickens with different necrotic enteritis challenge models. Poultry Science 2020, 99, 2452-2458, https://doi.org/10.1016/j.psj.2019.10.081.

49. Moradi, M.; Mardani, K.; Tajik, H. Characterization and application of postbiotics of Lactobacillus spp. on Listeria monocytogenes in vitro and in food models. LWT 2019, 111, 457-464, https://doi.org/10.1016/j.lwt.2019.05.072.

50. Rahmah, R.P.A.; Bahar, M.; Harjono, Y. Uji Daya Hambat Filtrat Zat Metabolit Lactobacillus plantarum Terhadap Pertumbuhan Shigella dysenteriae Secara In Vitro. Biogenesis: Jurnal Ilmiah Biologi 2017, 5, 3441, https://doi.org/10.24252/bio.v5i1.3431.

51. Moradi, M.; Tajik, H.; Mardani, K.; Ezati, P. Efficacy of lyophilized cell-free supernatant of Lactobacillus salivarius (Ls-BU2) on Escherichia coli and shelf life of ground beef. Veterinary research forum : an international quarterly journal 2019, 10, 193-198.

52. Baghban-Kanani, P.; Hosseintabar-Ghasemabad, B.; Azimi-Youvalari, S.; Seidavi, A.; Ragni, M.; Laudadio, V.; Tufarelli, V. Effects of using Artemisia annua leaves, probiotic blend, and organic acids on performance, egg quality, blood biochemistry, and antioxidant status of laying hens. The Journal of Poultry Science 2019, 56, 120-127, https://doi.org/10.2141/jpsa.0180050.

53. Baird, B.; Lucia, L.; Acuff, G.; Harris, K.; Savell, J. Beef hide antimicrobial interventions as a means of reducing bacterial contamination. Meat science 2006, 73, 245-248, https://doi.org/10.1016/j.meatsci.2005.11.023.

54. Mani-López, E.; García, H.; López-Malo, A. Organic acids as antimicrobials to control Salmonella in meat and poultry products. Food Research International 2012, 45, 713-721, https://doi.org/10.1016/j.foodres.2011.04.043.

55. Šušković, J.; Kos, B.; Beganović, J.; Leboš Pavunc, A.; Habjanič, K.; Matošić, S. Antimicrobial activitythe most important property of probiotic and starter lactic acid bacteria. Food Technology and Biotechnology 2010, 48, 296-307.

56. Hu, C.H.; Ren, L.Q.; Zhou, Y.; Ye, B.C. Characterization of antimicrobial activity of three Lactobacillus plantarum strains isolated from Chinese traditional dairy food. Food science \& nutrition 2019, 7, 1997-2005, https://doi.org/10.1002/fsn3.1025.

57. O’Connor, P.M.; Kuniyoshi, T.M.; Oliveira, R.P.; Hill, C.; Ross, R.P.; Cotter, P.D. Antimicrobials for food and feed; a bacteriocin perspective. Current Opinion in Biotechnology 2020, 61, 160-167, https://doi.org/10.1016/j.copbio.2019.12.023.

58. Gálvez, A.; Abriouel, H.; López, R.L.; Omar, N.B. Bacteriocin-based strategies for food biopreservation. International journal of food microbiology $\mathbf{2 0 0 7}, \quad$ 120, https://doi.org/10.1016/j.ijfoodmicro.2007.06.001. 
59. Kim, S.W.; Ha, Y.J.; Bang, K.H.; Lee, S.; Yeo, J.-H.; Yang, H.-S.; Kim, T.-W.; Lee, K.P.; Bang, W.Y. Potential of bacteriocins from Lactobacillus taiwanensis for producing bacterial ghosts as a next generation vaccine. Toxins 2020, 12, https://doi.org/10.3390/toxins 12070432.

60. Churchward, C.P.; Alany, R.G.; Snyder, L.A. Alternative antimicrobials: the properties of fatty acids and monoglycerides. Critical reviews in microbiology 2018, 44, 561-570, https://doi.org/10.1080/1040841X.2018.1467875.

61. Desbois, A.P. Potential applications of antimicrobial fatty acids in medicine, agriculture and other industries. Recent patents on anti-infective drug discovery 2012, 7, 111-122, https://doi.org/10.2174/157489112801619728.

62. Mali, J.K.; Sutar, Y.B.; Pahelkar, A.R.; Verma, P.M.; Telvekar, V.N. Novel fatty acid-thiadiazole derivatives as potential antimycobacterial agents. Chemical Biology \& Drug Design 2020, 95, 174-181, https://doi.org/10.1111/cbdd.13634.

63. Yoon, B.K.; Jackman, J.A.; Valle-González, E.R.; Cho, N.-J. Antibacterial free fatty acids and monoglycerides: biological activities, experimental testing, and therapeutic applications. International journal of molecular sciences 2018, 19, https://doi.org/10.3390/ijms 19041114.

64. Waghu, F.H.; Idicula-Thomas, S. Collection of antimicrobial peptides database and its derivatives: Applications and beyond. Protein Science 2020, 29, 36-42, https://doi.org/10.1002/pro.3714.

65. Makarova, K.S.; Wolf, Y.I.; Karamycheva, S.; Zhang, D.; Aravind, L.; Koonin, E.V. Antimicrobial peptides, polymorphic toxins, and self-nonself recognition systems in Archaea: an untapped armory for intermicrobial conflicts. MBio 2019, 10, e00715-00719, https://doi.org/10.1128/mBio.00715-19.

66. Hanson, M.A.; Dostalova, A.; Ceroni, C.; Poidevin, M.; Kondo, S.; Lemaitre, B. Synergy and remarkable specificity of antimicrobial peptides in vivo using a systematic knockout approach. Elife 2019, 8, https://doi.org/10.7554/eLife.44341.001.

67. Zasloff, M. Antimicrobial peptides of multicellular organisms. Nature 2002, 415, 389-395, https://doi.org/10.1038/415389a.

68. Reid, G. Probiotic Lactobacilli for urogenital health in women. Journal of clinical gastroenterology 2008, 42, S234-S236, https://doi.org/10.1097/MCG.0b013e31817f1298.

69. Cords, B. Sanitizers; Halogens, surface-active agents and peroxides. Antimicrobials in foods 1993, $469-537$.

70. Osborn, H.; Akoh, C. Structured lipids-novel fats with medical, nutraceutical, and food applications. Comprehensive reviews in food science and food safety 2002, 1, 110-120, https://doi.org/10.1111/j.15414337.2002.tb00010.x.

71. Liu, P.; Stenger, S.; Li, H.; Wenzel, L.; Tan, B.; Krutzik, S.; Ochoa, M.; Schauber, J.; Wu, K.; Meinken, C. Vitamin D3-Triggered Antimicrobial Response-Another Pleiotropic Effect beyond Mineral and Bone Metabolism: Toll-Like Receptor Triggering of a Vitamin D-Mediated Human Antimicrobial Response. Science 311: 1770-1773, 2006. Journal of the American Society of Nephrology 2006, 17, 2949-2953.

72. Georgieva, V.; Kamolvit, W.; Herthelius, M.; Lüthje, P.; Brauner, A.; Chromek, M. Association between vitamin $\mathrm{D}$, antimicrobial peptides and urinary tract infection in infants and young children. Acta Paediatrica 2019, 108, 551-556, https://doi.org/10.1111/apa.14499.

73. Rossi, M.; Amaretti, A.; Raimondi, S. Folate production by probiotic bacteria. Nutrients 2011, 3, 118-134, https://doi.org/10.3390/nu3010118.

74. Pedrós-Garrido, S.; Clemente, I.; Calanche, J.; Condón-Abanto, S.; Beltrán, J.; Lyng, J.; Brunton, N.; Bolton, D.; Whyte, P. Antimicrobial activity of natural compounds against listeria spp. and their effects on sensory attributes in salmon (Salmo salar) and cod (Gadus morhua). Food Control 2020, 107, https://doi.org/10.1016/j.foodcont.2019.106768.

75. Homayouni-rad A, Oroojzadeh P, Abbasi A. The Effect of Yeast Kluyveromyces marxianus as a Probiotic on the Microbiological and Sensorial Properties of Set Yoghurt during Refrigerated Storage. Journal of Ardabil University of Medical Sciences 2021, 10, 254-68, http://jarums.arums.ac.ir/article-1-1924-en.html.

76. Guilhaumou, R.; Benaboud, S.; Bennis, Y.; Dahyot-Fizelier, C.; Dailly, E.; Gandia, P.; Goutelle, S.; Lefeuvre, S.; Mongardon, N.; Roger, C. Optimization of the treatment with beta-lactam antibiotics in critically ill patients - guidelines from the French Society of Pharmacology and Therapeutics (Société Française de Pharmacologie et Thérapeutique-SFPT) and the French Society of Anaesthesia and Intensive Care Medicine (Société Française d'Anesthésie et Réanimation-SFAR). Critical Care 2019, 23, https://doi.org/10.1186/s13054-019-2378-9.

77. Gómez-Sala, B.; Herranz, C.; Díaz-Freitas, B.; Hernández, P.E.; Sala, A.; Cintas, L.M. Strategies to increase the hygienic and economic value of fresh fish: Biopreservation using lactic acid bacteria of marine origin. International journal of food microbiology 2016, 223, 41-49, https://doi.org/10.1016/j.ijfoodmicro.2016.02.005.

78. Manson, A.L.; Van Tyne, D.; Straub, T.J.; Clock, S.; Crupain, M.; Rangan, U.; Gilmore, M.S.; Earl, A.M. Chicken meat-associated enterococci: influence of agricultural antibiotic use and connection to the clinic. Applied and environmental microbiology 2019, 85, https://doi.org/10.1128/AEM.01559-19.

79. Mostafa, G.; Mokhtar, M.; Eldeep, G. Effect of bacteriocins (from Bifidobacterium spp.) on prevalence of some Aeromonas and Pseudomonas species in minced meat during cold storage. American Journal of Food Science and Nutrition 2016, 2, 55-67, https://doi.org/10.4172/2324-9323.1000188. 
80. Hamad, G.M.; Abdelmotilib, N.M.; Darwish, A.M.; Zeitoun, A.M. Commercial probiotic cell-free supernatants for inhibition of Clostridium perfringens poultry meat infection in Egypt. Anaerobe 2020, 62, https://doi.org/10.1016/j.anaerobe.2020.102181.

81. Moradi, M.; Kousheh, S.A.; Almasi, H.; Alizadeh, A.; Guimarães, J.T.; Y1lmaz, N.; Lotfi, A. Postbiotics produced by lactic acid bacteria: The next frontier in food safety. Comprehensive Reviews in Food Science and Food Safety 2020, 19, 3390-3415, https://doi.org/10.1111/1541-4337.12613.

82. Urish, K.L.; DeMuth, P.W.; Kwan, B.W.; Craft, D.W.; Ma, D.; Haider, H.; Tuan, R.S.; Wood, T.K.; Davis, C.M. Antibiotic-tolerant Staphylococcus aureus biofilm persists on arthroplasty materials. Clinical Orthopaedics and Related Research® 2016, 474, 1649-1656, https://doi.org/10.1007/s11999-016-4720-8.

83. Miao, J.; Liang, Y.; Chen, L.; Wang, W.; Wang, J.; Li, B.; Li, L.; Chen, D.; Xu, Z. Formation and development of Staphylococcus biofilm: with focus on food safety. Journal of Food Safety 2017, 37, https://doi.org/10.1111/jfs.12358.

84. Przekwas, J.; Wiktorczyk, N.; Budzyńska, A.; Wałecka-Zacharska, E.; Gospodarek-Komkowska, E. Ascorbic Acid Changes Growth of Food-Borne Pathogens in the Early Stage of Biofilm Formation. Microorganisms 2020, 8, https://doi.org/10.3390/microorganisms8040553.

85. Andrade, J.C.; João, A.L.; Alonso, C.d.S.; Barreto, A.S.; Henriques, A.R. Genetic Subtyping, BiofilmForming Ability and Biocide Susceptibility of Listeria monocytogenes Strains Isolated from a Ready-to-Eat Food Industry. Antibiotics 2020, 9, https://doi.org/10.3390/antibiotics9070416.

86. Shi, X.; Zhu, X. Biofilm formation and food safety in food industries. Trends in Food Science \& Technology 2009, 20, 407-413, https://doi.org/10.1016/j.tifs.2009.01.054.

87. Sharma, V.; Harjai, K.; Shukla, G. Effect of bacteriocin and exopolysaccharides isolated from probiotic on P. aeruginosa PAO1 biofilm. Folia microbiologica 2018, 63, 181-190, https://doi.org/10.1007/s12223-0170545-4.

88. Izuddin, W.I.; Humam, A.M.; Loh, T.C.; Foo, H.L.; Samsudin, A.A. Dietary Postbiotic Lactobacillus plantarum Improves Serum and Ruminal Antioxidant Activity and Upregulates Hepatic Antioxidant Enzymes and Ruminal Barrier Function in Post-Weaning Lambs. Antioxidants 2020, 9, https://doi.org/10.3390/antiox9030250.

89. Humam, A.M.; Loh, T.C.; Foo, H.L.; Izuddin, W.I.; Zulkifli, I.; Samsudin, A.A.; Mustapha, N.M. Supplementation of postbiotic RI11 improves antioxidant enzyme activity, upregulated gut barrier genes, and reduced cytokine, acute phase protein, and heat shock protein 70 gene expression levels in heat-stressed broilers. Poultry Science 2021, 100, https://doi.org/10.1016/j.psj.2020.12.011.

90. Mirnejad, R.; Vahdati, A.R.; Rashidiani, J.; Erfani, M.; Piranfar, V. The antimicrobial effect of lactobacillus casei culture supernatant against multiple drug resistant clinical isolates of Shigella sonnei and Shigella flexneri in vitro. Iranian Red Crescent medical journal 2013, 15.

91. Le, N.T.T.; Bach, L.G.; Nguyen, D.C.; Le, T.H.X.; Pham, K.H.; Nguyen, D.H.; Hoang Thi, T.T. Evaluation of factors affecting antimicrobial activity of bacteriocin from Lactobacillus plantarum microencapsulated in alginate-gelatin capsules and its application on pork meat as a bio-preservative. International journal of environmental research and public health 2019, 16, https://doi.org/10.3390/ijerph16061017.

92. Silva, D.R.; Sardi, J.d.C.O.; de Souza Pitangui, N.; Roque, S.M.; da Silva, A.C.B.; Rosalen, P.L. Probiotics as an alternative antimicrobial therapy: Current reality and future directions. Journal of Functional Foods 2020, 73, https://doi.org/10.1016/j.jff.2020.104080.

93. Abbasi A.; Hajipour N.; Hasannezhad P.; Baghbanzadeh A.; Aghebati-Maleki L. Potential in vivo delivery routes of postbiotics. Critical Reviews in Food Science and Nutrition 2020, 1-39, https://doi.org/10.1080/10408398.2020.1865260.

94. Rathore, S.; Desai, P.M.; Liew, C.V.; Chan, L.W.; Heng, P.W.S. Microencapsulation of microbial cells. Journal of Food Engineering 2013, 116, 369-381, https://doi.org/10.1016/j.jfoodeng.2012.12.022.

95. Anwar, F.; Altayb, H.N.; Al-Abbasi, F.A.; Al-Malki, A.L.; Kamal, M.A.; Kumar, V. Antiviral effects of probiotic metabolites on COVID-19. Journal of Biomolecular Structure and Dynamics 2020, 1-10, https://doi.org/10.1080/07391102.2020.1775123.

96. Koirala, R.; Gargari, G.; Arioli, S.; Taverniti, V.; Fiore, W.; Grossi, E.; Anelli, G.M.; Cetin, I.; Guglielmetti, S. Effect of oral consumption of capsules containing Lactobacillus paracasei LPC-S01 on the vaginal microbiota of healthy adult women: a randomized, placebo-controlled, double-blind crossover study. FEMS microbiology ecology 2020, 96, https://doi.org/10.1093/femsec/fiaa084. 